\title{
PENINGKATAN KETERAMPILAN REMAJA DENGAN PELATIHAN TEKNISI PC UNTUK SISWA SMK SYUHADA BANJARMASIN
}

\author{
Asrul Sudiarl, Akbar Ela Heka ${ }^{2}$, Rinova Firma Cahyani ${ }^{3}$, Norhafani ${ }^{4}$ \\ Politeknik Negeri Banjarmasin ${ }^{1,2,3,4}$ \\ asrulsudiar@poliban.ac.id ${ }^{l}$
}

\begin{abstract}
ABSTRAK
Pengetahuan dan keterampilan dasar dalam mengoperasikan komputer saat ini sudahlah menjadi kebutuhan yang tidak dapat dihindari lagi. Berbagai kegiatan atau aktivitas hidup manusia di jaman moderen ini tidak dapat lepas dengan bantuan komputer untuk membuatnya menjadi lebih mudah, cepat dan efektif. Sebagai contohnya aktivitas pekerjaan manusia yang berkaitan dengan komputer diantaranya: pekerjaan dengan pengolah kata (word processing), pekerjaan dengan tabel (table processing), membaca berita, browsing artikel di internet, bermain game, mengirim dan menerima email. Begitu banyaknya tugas pekerjaan manusia yang dapat dikerjakan dengan bantuan komputer membuat banyak orang yang berlomba-lomba untuk memiliki perangkat ini. Namun tidak semua orang memiliki kemampuan untuk memperbaiki jika suatu saat komputer yang digunakan mengalami kerusakan.

Banyaknya pengguna komputer di lingkungan remaja khususnya pelajar di tingkat SLTA/SMK disekitar lingkungan daerah kayutangi Banjarmasin tidak diiringi dengan banyaknya tenaga yang ahli dalam memperbaiki komputer jika terjadi kerusakan menjadi suatu permasalahan tersendiri. Tidak sedikit kejadian dimana bila terjadi kerusakan pada komputer yang dimiliki maka pengguna akan membawa komputer mereka ke tempat servis komputer yang tentu saja memerlukan biaya servis yang tidaklah murah. Sebagai solusi maka dalam pengabdian masyarakat tahun ini kami ingin memberikan pelatihan teknisi PC (Personal Computer) kepada remaja usia SLTA/SMK di lingkungan kayutangi Banjamasin. Tujuan dari pelatihan teknisi PC ini nantinya adalah agar peserta pelatihan memiliki keterampilan dan dapat melakukan perbaikan, perakitan dan upgrade PC sendiri. Metode pelatihan yang digunakan pada pelatihan ini nantinya adalah kombinasi dari teori dan praktek sehingga diharapkan akan memudahkan peserta untuk menguasai materi yang diberikan. Target luaran dari kegiatan pengabdian masyarakat ini adalah jasa pelatihan keterampilan dan publikasi yang akan diterbitkan adalah jurnal pengabdian nasional.
\end{abstract}

Keyword: Pelatihan Teknisi PC, Pengabdian Masyarakat

\section{PENDAHULUAN}

Banyaknya remaja pengguna komputer di SLTA maupun SMK yang tidak memiliki pengetahuan dan keterampilan dalam memperbaiki komputer dan mahalnya biaya perbaikan yang harus dikeluarkan jika memperbaiki komputer di tempat servis komputer, adalah dua permasalahan yang sering dihadapi mitra saat ini. Berdasar dari pertimbangan tersebut maka pengabdian masyarakat ini akan 
menyelenggarakan pelatihan teknisi PC untuk remaja di SLTA maupun SMK tersebut, untuk menyelesaikan permasalah yang ada tersebut.

Adapun kegiatan pengabdian masyarakat ini dalam rangka memberikan wawasan dan keterampilan kepada siswa SMK Syuhada Banjarmasin dalam bidang merakit, melakukan upgrade komponen dan melakukan perbaikan komputer (PC). Secara rinci tujuan dan manfaat dari kegiatan ini adalah sbb:

- Memberikan wawasan tentang pengetahuan dasar komponen-komponen utama penyusun sebuah PC serta cara memilih spesifikasinya sesuai dengan kebutuhan.

- Memberikan keahlian kepada siswa tentang teknik merakit komponen PC yang benar.

- Memberikan keahlian melakukan upgrade komponen dan perbaikan PC.

\section{METODE KEGIATAN / SOLUSI / TEKNOLOGI /}

Metode yang digunakan dalam pelatihan teknisi PC ini adalah metode proses pembelajaran dengan penyampaian teori dan diikuti dengan kegiatan praktek. Adapun kegiatan dalam pelatihan ini dan metode yang digunakan adalah sbb:

Tabel 1: Rincian Kegiatan Pelatihan

\begin{tabular}{|c|c|c|c|}
\hline No. & Kegiatan Pelatihan & Metode & Kegiatan Peserta \\
\hline 1. & $\begin{array}{lll}\begin{array}{l}\text { Pengenalan } \\
\text { software }\end{array} & \text { hardware dan } \\
\end{array}$ & Penyampaian teori & Menyimak materi \\
\hline 2. & $\begin{array}{l}\text { Pengenalan komponen utama } \\
\text { komputer }\end{array}$ & $\begin{array}{l}\text { Penyampaian teori } \\
\text { dan menunjukkan } \\
\text { komponen. }\end{array}$ & $\begin{array}{l}\text { Menyimak materi } \\
\text { dan } \\
\text { memperhatikan } \\
\text { komponen secara } \\
\text { langsung }\end{array}$ \\
\hline 3. & Pengenalan mainboard PC & $\begin{array}{l}\text { Penjelasan nama } \\
\text { komponen pada } \\
\text { mainboard beserta } \\
\text { fungsinya }\end{array}$ & $\begin{array}{l}\text { Menyimak materi } \\
\text { dan } \\
\text { memperhatikan } \\
\text { komponen secara } \\
\text { langsung. }\end{array}$ \\
\hline 4. & $\begin{array}{l}\text { Pengenalan berbagai kabel data } \\
\text { pada PC }\end{array}$ & $\begin{array}{l}\text { Penyampaian teori } \\
\text { dan menunjukkan } \\
\text { komponen. }\end{array}$ & $\begin{array}{l}\text { Menyimak materi } \\
\text { dan } \\
\text { memperhatikan } \\
\text { komponen secara } \\
\text { langsung. }\end{array}$ \\
\hline 5. & $\begin{array}{l}\text { Praktek membongkar/melepas } \\
\text { komponen pada PC }\end{array}$ & Teori dan & $\begin{array}{l}\text { Melakukan praktek } \\
\text { membongkar } \\
\text { komponen } \\
\text { dengan } \\
\text { yang benar. }\end{array}$ \\
\hline 6. & Praktek merakit komponen PC & Teori dan Praktek & $\begin{array}{l}\text { Melakukan praktek } \\
\text { merakit komponen }\end{array}$ \\
\hline
\end{tabular}




\begin{tabular}{|l|l|l|l|}
\hline & & & $\begin{array}{l}\text { PC dengan urutan } \\
\text { yang benar. }\end{array}$ \\
\hline 7. & $\begin{array}{l}\text { Praktek mempartisi hardisk dan } \\
\text { menginstal sistem operasi }\end{array}$ & Teori dan Praktek & $\begin{array}{l}\text { Melakukan praktek } \\
\text { menginstal OS. }\end{array}$ \\
\hline
\end{tabular}

\section{HASIL DAN PEMBAHASAN}

Untuk dapat melihat hasil dan luaran yang dicapai dari kegiatan pelatihan ini diperlukan beberapa kegiatan tes sebelum dan sesudah kegiatan pelatihan dilaksanakan. Adapun tes yang diberikan berupa PreTest diawal pertemuan dan PostTest sesudah pelatihan. Tujuan dari pemberian PreTest adalah untuk menilai sejauh mana pemahaman peserta sebelum kegiatan pelatihan dilaksanakan, sedangkan pemberian PostTest bertujuan untuk mengetahui sejauh mana hasil pemahaman peserta terhadap pelaksanaan pelatihan ini. Berikut hasil penilaian terhadap dua jenis tes tersebut:

Tabel 2: Penilaian Peserta Pelatihan

\begin{tabular}{|c|l|c|c|c|}
\hline \multirow{2}{*}{ No. } & \multirow{2}{*}{ Nama Peserta } & \multirow{2}{*}{ Kelas \& Jurusan } & \multicolumn{2}{|c|}{ Hasil Tes } \\
\cline { 4 - 5 } & & XII TKR B & 45 & 60 \\
\hline 1 & Irpan Maulana & XII TKR B & 60 & 95 \\
\hline 2 & Alvin Rissieanto & XII TKR B & 50 & 65 \\
\hline 3 & Irpansyah & XII TKR B & 40 & 60 \\
\hline 4 & Muhammad Noor & XII TKR B & 55 & 88 \\
\hline 5 & Asmiadi & XII TKR B & 65 & 88 \\
\hline 6 & Ahmad Rizaldi & XII TKR B & 60 & 90 \\
\hline 7 & Yhoga Dwi Cahyono & XII TKR A & 60 & 78 \\
\hline 8 & Ali Syahbana & XII TKR B & 55 & 65 \\
\hline 9 & M. Kevin Ardanang & XII TKR B & 60 & 88 \\
\hline 10 & Edi Suriyanto & XII TKR B & 58 & 78 \\
\hline 11 & Faisal Febrianto & XII TKR B & 65 & 88 \\
\hline 12 & Madi & & & \\
\hline
\end{tabular}

\section{Keterangan:}

- Setelah melakukan kedua tes diatas dapat dilihat bahwa terjadi peningkatan nilai/skor pemahaman peserta terhadap materi teori maupun praktek saat pelatihan ini selesai dilaksanakan. 


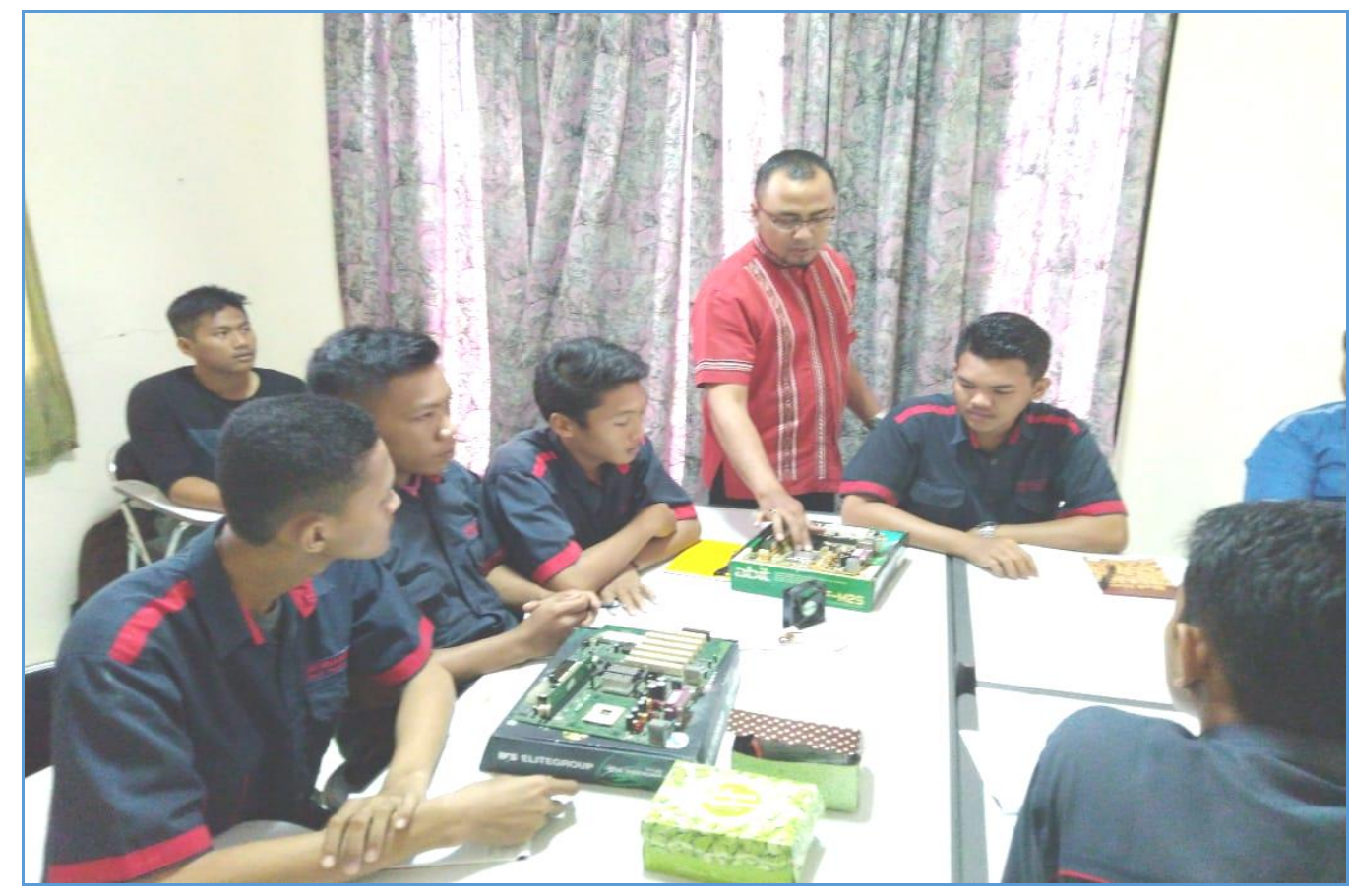

Gambar 1: Materi Dasar Pengenalan Disain Mainboard

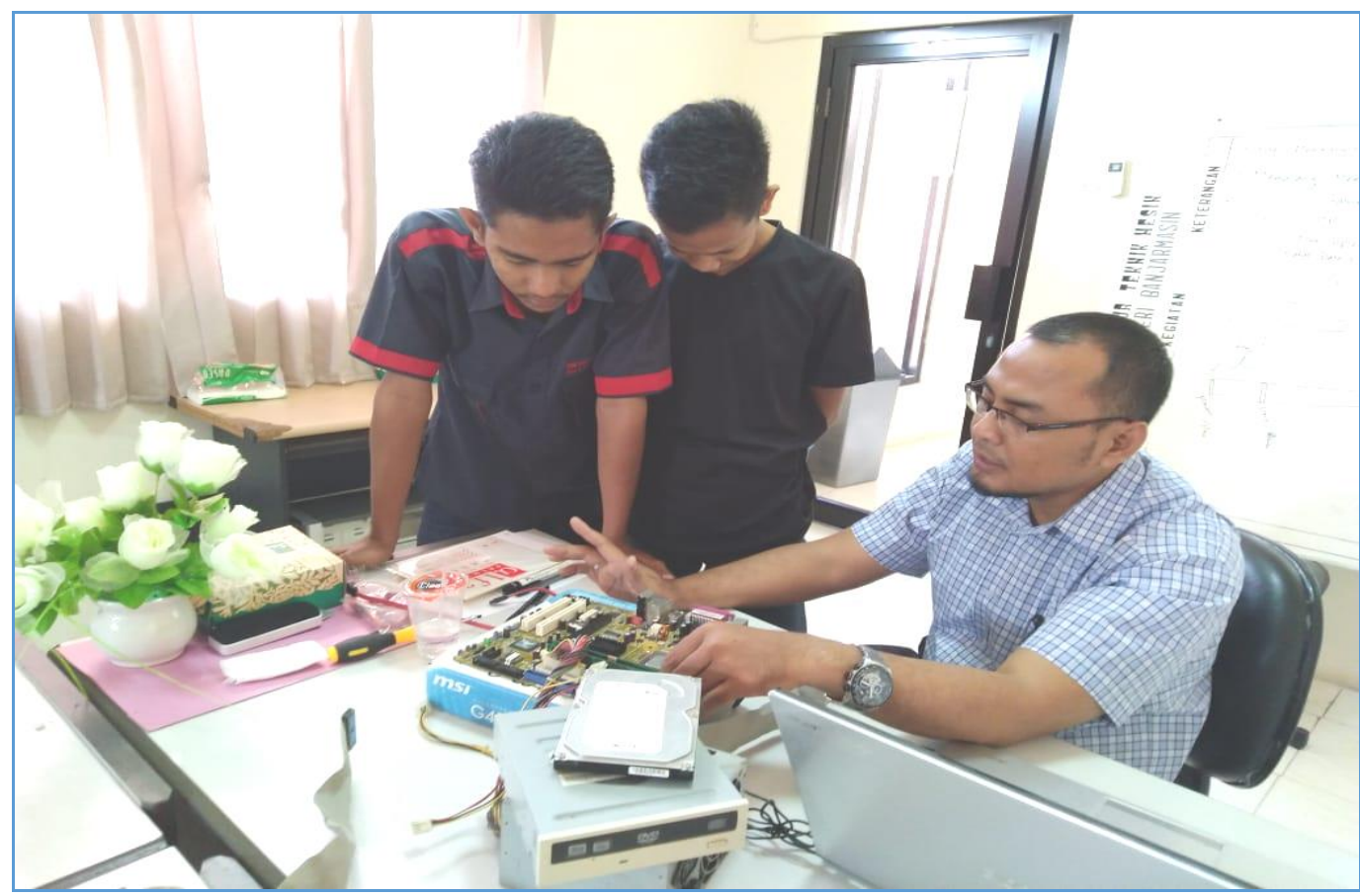

Gambar 2: Praktek Merangkai Komponen PC 


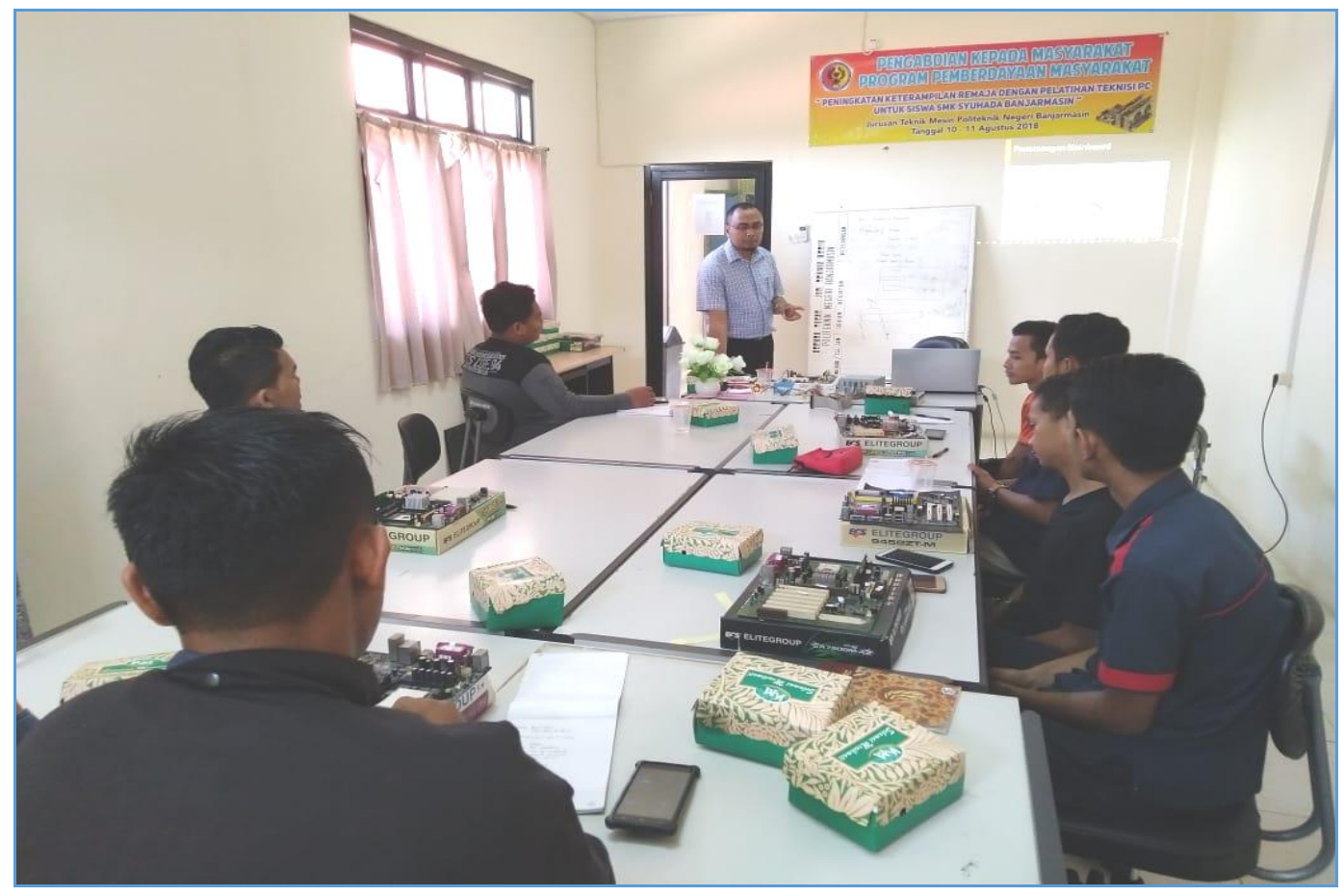

Gambar 3: Praktek Mengenal Konektor Power dan Data

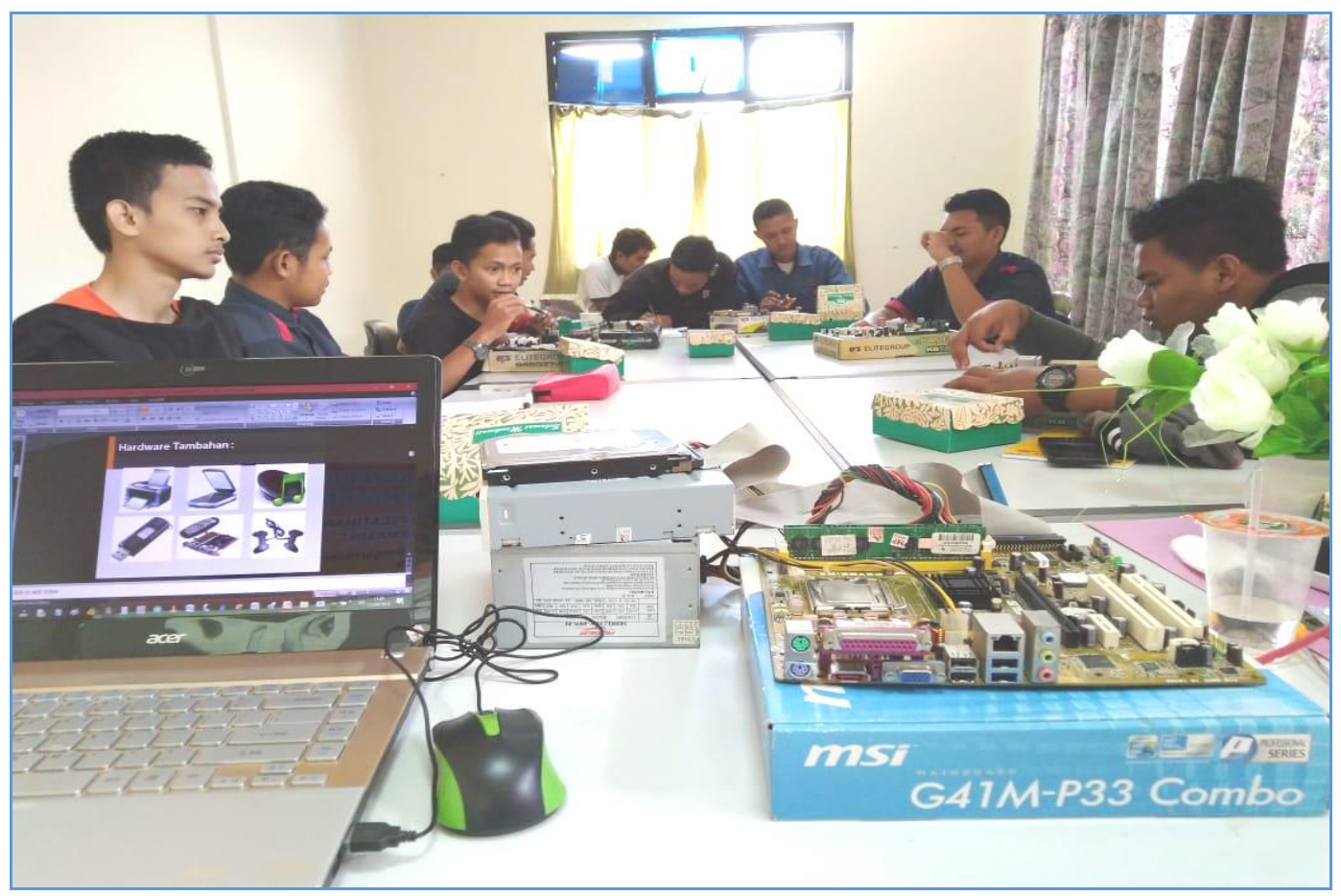

Gambar 4: Praktek Merakit Komponen PC 


\section{KESIMPULAN}

Kegiatan pengabdian ini mendapatkan respon positif dari pihak sekolah khususnya SMK Syuhada Banjarmasin yang menjadi mitra kami. Selama kegiatan para siswa yang menjadi peserta pelatihan dapat mengikuti semua materi yang diberikan oleh instruktur, mulai dari pengenalan teori dasar sampai dengan praktek merakit komponen PC dengan baik. Hal ini dapat dilihat dari antusiasnya peserta saat praktek merakit komponen PC. Walaupun dalam pelaksanaannya pasti ditemui kendala berupa kesalahan dalam pemasangan kabel power maupun kabel data saat proses instalasi berlangsung namun hal ini merupakan hal yang wajar bagi pemula dalam bidang ini

\section{DAFTAR PUSTAKA}

Panduan Pelaksanaan Penelitian dan Pengabdian Pada Masyarakat di Perguruan Tinggi Edisi XII Tahun 2018. Direktorat Riset dan Pengabdian Pada Masyarakat, Direktorat Jenderal Penguatan Riset dan Pengembangan, Kementerian Riset, Teknologi dan Pendidikan Tinggi.

Rencana Strategis Pengabdian Kepada Masyarakat Politeknik Negeri Banjarmasin Tahun 2017-2021.

A. Hermansyah, "Buku Panduan Merakit Komputer", Filla Press, 2011

Suyitno,"Pelatihan Komputer Bagi Perangkat Desa dan Karang Taruna di Purworejo", Laporan Pengabdian Masyarakat, 2018.

Febrian. Jack, Kamus Komputer \& Teknologi Informasi.Informatika, Informatika Bandung, 2007

Hartono, Pengenalan Komputer, Andi Yogyakarta, 2011 